\title{
Giftedness and Creativity of Students and Teachers in the Process of Education
}

\author{
Ruzica Petrovic ${ }^{1}$, Vesna Trifunovic ${ }^{1} \&$ Radmila Milovanovic $^{1}$ \\ ${ }^{1}$ Faculty of Pedagogical Sciences, University of Kragujevac, Jagodina, Serbia \\ Correspondence: Ruzica Petrovic, Faculty of Pedagogical Sciences, University of Kragujevac, Jagodina, Serbia. \\ E-mail: prof.ruzica@gmail.com
}

Received: April 26, 2013 Accepted: May 24, 2013 Online Published: June 24, 2013

doi:10.5539/ies.v6n7p111 URL: http://dx.doi.org/10.5539/ies.v6n7p111

\begin{abstract}
This paper conceptually defines the categories of giftedness and creativity and associates them with the role of teachers and students in their realization in the process of education. It examines the basic abilities that a teacher should possess and the methods that should be used for proper identification of students' potential and for their overall development. Giftedness is not reduced to the rational intelligence but is understood in the context of wider spiritual content for the identification of which the enhanced creative sensibility of teachers is essential.

Ways in which teachers can encourage students' creative energy are: a) recognizing wonderment as the basic cognitive impulse, b) identifying and motivating curiosity as a good way of introducing the process of free-thinking, c) developing the gift of observation as an ability of keen sensual and spiritual perception, with which one can discover latent creative energy, d) fostering eloquence as the basis for successful development of verbal communication skills, f) strengthening moral qualities as an assumption of feelings of safety, empathy, motivation of the spirit of tolerance and formation of a positive attitude to life.
\end{abstract}

Keywords: giftedness, creativity, education, intellect, morality

\section{Introduction}

Adequate theoretical and practical approaches to the phenomenon of giftedness and creativity imply their conceptual definition. There are numerous theories that deal with giftedness in different ways. Depending on whether they follow the entire developmental process of gifted individuals from their predispositions to specific achievements, or deal with intellectual and cognitive processes, two basic theoretical orientations can be distinguished: developmental and cognitive. A holistic approach to the phenomenon of giftedness involves respecting the results of study of both approaches (Sternberg \& Davidson, 1986). In the context of these theoretical orientations there are a number of definitions that reveal the complex nature of the phenomenon of giftedness through the character structure of personality (Sternberg 1986), through activity (Renzulli, 1986) focused on the specific area and through the accomplished achievement (Gagné, 1994). Some authors see giftedness as a common feature that gives a unique character to its carriers, regardless of their area of giftedness, while others distinguish the gifted by the type of their predispositions and forms of expression through concrete activities in specific areas. (F. J. Monks, N. W. Katzko \& H. W. 1992).

Unlike adults whose giftedness can be recognized through their achievements, children usually display their giftedness through the ability to solve tasks and through possessing a higher level of knowledge in the area where their giftedness is manifested. (Borkowski \& Peck 1986, 182). However, very often, it is not easy to determine whether task solving has its foundation in giftedness or in the larger amount of knowledge. Hence, many authors see the dividing line in the creative potential of a person, assuming that true giftedness must provide unexpected, original and surprising answers (Cropley, 1993). One of important dimensions of giftedness is a factor of motivation and self-awareness. In this context, great interest in a particular area, good work results and high core self-evaluation, cannot in themselves be a sure indicator of giftedness. Also it is very difficult to assess whether decreased motivation to learn, the presence of doubt in one's own ability, negative self-observation, show a lack of talent. (Feldhusen J., 1986).

The role of education in encouraging giftedness and creativity is very important and therefore teachers' insight into these categories should provide a greater sensitivity to their recognition and expression among students. 
According to the principle "it takes one to know one", for teachers to recognize giftedness in others they too need to be gifted, and in order to enco urage the creative impulse in others they need to create in conditions of complete freedom.

Studies have shown that it is possible to identify gifted children even at preschool age; however, manifestation of giftedness in the form of interests and activities is not sufficient. What is also necessary is to carry out giftedness-focused observation of a child as well as to have institutional strategy built into upbringing-educational curricula. Strategies for identification of the gifted in preschool institutions and schools involve intuition and experiences of teachers, curriculum instructions on how to identify gifted students, engagement of professional associates (pedagogues and psychologists), as well as methodology and models suggested by acknowledged scientists dealing with the issue of identification of the gifted (Siegler- Kotovsky 1986: 414-436).

Table 1. Phase model of identification of the gifted (Dai D., Swanson J., Cheng H. 2011)

\begin{tabular}{llll}
\hline \multicolumn{1}{c}{ PHASE } & RECOGNITION & IDENTIFICATION & VERIFICATION \\
\hline TARGET GROUP & Student population & Potentially gifted & Manifested gifted \\
NOMINATORS & Teachers, & Interdisciplinary team & Professional team \\
& Parents, & & \\
& Students & & \\
\hline
\end{tabular}

Giftedness of teachers, therefore, implies not only abilities of intellectual nature through which the necessary scientific and methodological knowledge is acquired, but also gifts that go beyond the strictly logical and rational, and refer to the mental and spiritual powers, such as empathy, intuition, imagination, creative imagination and fantasy. These powers enable teachers to sense the internal states of students which by looking superficially, without empathy, could not be perceived. The lack of such "sense" very often leads to teachers forming an opinion about the students' abilities solely on the basis of their results and behavior, which then leads to lack of ability to recognize the potential of highly gifted students.

Research shows that teachers often do not recognize the giftedness of students who display lack of attention in class, who are inquisitive, who do not pay attention to a lecture, or display some form of inappropriate behavior, which can be perceived as a symptom of their latent dissatisfaction with the current way of work. These kinds of contradictions can be clarified by Plato's stance: "Even those with innate good qualities may not find it sufficient to create a good life: without proper guidance they too can wander from the way of goodness... And the claim that the most gifted minds, when they are ill-educated, become pre-eminently bad is also justified. Have great crimes and shameful acts sprung from average people, and not from a fullness of nature ruined by education?"(Plato 2003, 592)

This must particularly be taken into account when considering the complex natures, i.e. the multi-gifted, because satisfying the curiosity of a gifted nature is much more difficult than that of low potential. Complex natures can develop their full potential only if they get proper education. That means that anyone who is truly eager for knowledge, naturally tends not to be satisfied by superficial knowledge, but, driven by the power of spiritual energy seeks a deeper understanding of things. Otherwise, i.e. in conditions that do not correspond to one's nature, one can become completely degraded, because "the finest natures, when under alien conditions, receive more injury than the inferior, because the contrast is greater". (Plato, 2002).

\section{Interaction of Giftedness and Creativity}

An attempt to conceptually define the phenomenon of giftedness and creativity raises questions in three areas. The metaphysical, where gifts are considered God's grace. Then, the ontological, where giftedness is associated with man's entitlement to embody the gifts and bring them back to the original source - amplified. And anthropological, where one creatively relates to gifts through participation in changing the world and himself.

Therefore, a man is born as a being bestowed with different energies. The bigger the gift received the greater one's entitlement to its realization. By these gifts, no matter their type and degree of excellence, a man stands open with the ability to recognize and improve them or to ignore and fail them. Nevertheless, they determine one's role in the world because they call upon the realization of one's own nature and the meaning of one's existence. Nature has fortunately arranged things so that every man who has inherited a remarkable gift feels the 
need to realize it. This need is expressed through a special kind of sublimated energy that drives the creation, which Plato called "Spiritual Eros" or "Royal Desire" that "gives Psyche her wings", and without which no creative work would be made possible (Plato, 2003). However, in gifts dwells not only the need to express them, but the duty of their realization and improvement. Socrates called such tendency the "Inner Voice" that he himself could hear and that would warn him of what to do and what to stay away from, and Aristotle had brought it in immediate connection with happiness considering that, if one wants to achieve the greatest good, one should live in accordance with one's best intellectual and moral faculties, and if there are more than one such faculties, then in accordance with the best one. (Aristotle, 2002)

By the 1950's the research became far more focused on the study of giftedness than creativity, and the phenomenon of giftedness was mainly reduced to the study of intelligence. Studying creativity Guilford found that there are two ways of thinking: convergent (logical) and divergent (creative). The first moves in an expected, conventional way of logical operations, while the latter goes in several directions, with the characteristics of fluency, flexibility and originality, which makes it closer to creative work and behavior.

Among contemporary theories of giftedness Sternberg's theory (Sternberg, 1986) should be distinguished, which is based on the theory of intelligence and, as such, is expressed as a special kind of intellectual giftedness. He believes that at the basis of giftedness lies extraordinary and unusual intelligence that can give giftedness the character of academic or creative giftedness. (Sternberg \& Lubart, 1993). Preference is given to the latter because he believes that people who possess it step out of conventional way of thinking and the existing system of ideas. They are very successful in defining the problem, strategic use of divergent thinking and skills of selective coding, comparing and combining information (Maksic, 2007). Creative gifted individuals are characterized by a high level and quality of knowledge, great commitment to the object of study, ability of mental management in all phases of work, specific structure of personality traits. Renzuli (Renzulli, 1986) also points out the connection of giftedness and creativity through the theory of gifted behavior which in addition to intellectual ability includes intense motivation to solve certain problems and creative potential, fluency, flexibility, openness to new experiences, curiosity, sensitivity, productivity.

Figure below (Figure 1) shows the responses of preschool teachers, class teachers and teachers given in the research on giftedness concept conducted on the sample of 150 subjects ( 50 preschool teachers, 50 class teachers and 50 teachers from various towns in Serbia) in 2010/11 (Milovanovic, 2012).

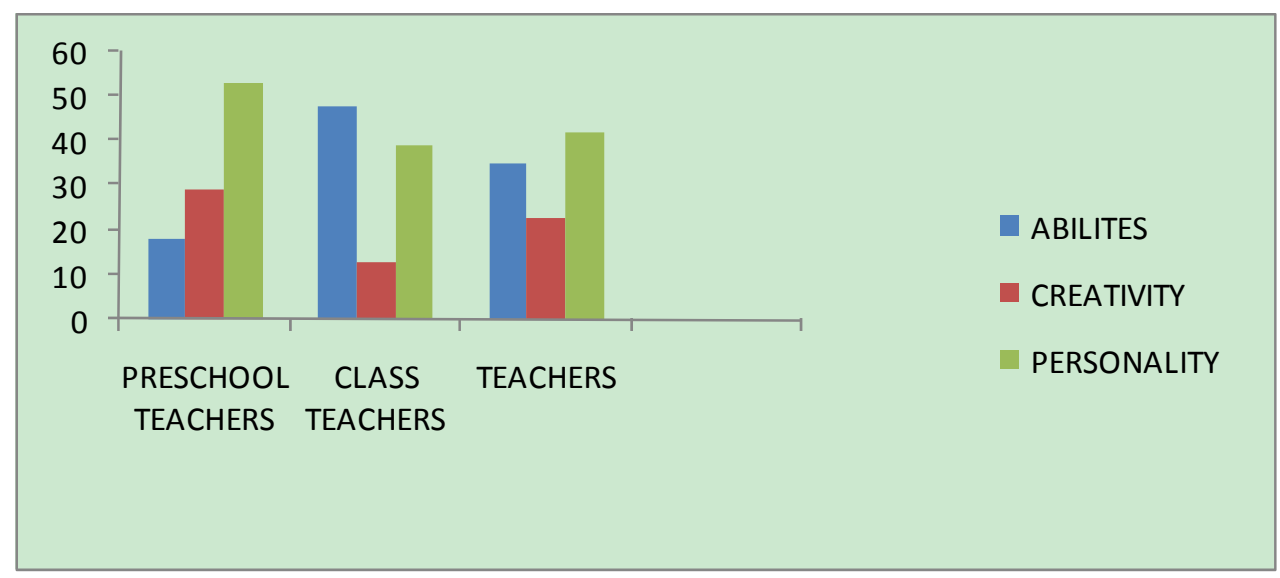

Figure 1. Distribution of abilities, creativity and personality traits in giftedness concept in the case of the examined preschool teachers, class teachers and teachers (expressed in \%)

Preschool teachers' view on giftedness is dominated by personality traits, followed by creativity and the least significant role is attributed to abilities. Unlike them, class teachers' understanding of giftedness is dominated by abilities, followed by personality traits and the least significant role is attributed to creativity; in regard to teachers, the most significant role belongs to abilities as well as personality traits, while creativity is also important but it is at the third place. The mentioned research has shown that there is confusion in the notional system of the examined subjects, as well as the lack of a general strategy in the field of giftedness; as a result, pre-school teachers, class teachers and teachers are often in a situation to actually ask themselves: what to do with gifted children? 
More conceptual comprehension of the category of creativity necessarily raises questions, who creates, what is created, out of what, i.e. questions about the creator, the created world and the energy of creation? In this sense we can speak of God's creation as "creatio originalis" out of which the created world stemmed from, and with it a reality open to further changes "creatio continua" and the ability to act in the world "creation nova" (Moltman J., 1988). The latter implies that a man is called upon to act in the created world and to participate in its transformation. If we ask ourselves about the nature of creation, then we can say that its nature is based on the effects of different energies. As a force, they exist in a man, nature and the universe, and permeate the whole existence. Therefore, we can only partially abstract a man and the energies in him, because everything exists as a single living organism through which the joint forces are pulsing. Therefore, "though free to think and to act, we are held together like the stars in firmament with ties inseparable. These ties cannot be seen, but we can feel them... Each of us is only part of a Whole." (N. Tesla 1995: 93) If, therefore, we follow the bond of unity, profusion, interdependence and harmony of all that exists, we come to a common source where everything was created, and the substance of which puts everything in motion. Thus, the phenomenon of creation raises the question of the source, i.e. the initiator of creation. N. Tesla believed that it is a primary matter, incomprehensibly tenuous, out of which the creative force that introduces the existence acts. That's why he said: "And all this movement from the surging of the mighty ocean to that subtle movement concerned in our thought, has but one common cause. All this energy emanates from one single center, one single source - the Sun." (ibid., 94).

Research, discoveries, findings are the greatest confirmation of a man "plugged-in in the mechanism of the universe" and the expression of his deepest desire to participate in the "creation of miracles that he observes around him" and that are created by nature. That is why creation is an act of freedom in which something entirely new is created. However, man's creation would not be possible without this already created world on the surface of which he acts. It is a unique encounter of a man and the world in which different energies move, merge and form.

Human creativity is born in a torrent of passion that strongly overtakes a nascent idea. Therefore, at first it takes the form of intuition, anticipation, immediate idea that attracts and preoccupies the soul with irresistible force. That primary creative act is the source of excitement and mystery in which the potential creator feels the force of the internal motion. But to truly achieve creative energy, it needs to come down into the world and reveal itself through concrete forms, but here lies the possibility of its prevention. Although the most important thing when shaping the creative energy into a certain creation is choseness, i.e. bestowed grace and effort, external conditions in which their union is freely exercised are also very important. This is why, when we talk about the creativity of students, there is a responsibility of teachers in identifying giftedness and creating the conditions for its free development. The task is even more delicate when children are of age when their abilities have not yet reached differentiation and maturity. Teachers are expected to possess a high degree of sensitivity not only in recognizing the abilities, but also in stimulating the creative nature of their expression. This is very important, because a child can feel and deduce the presence of creative powers far better than understand or have a clear awareness of them. Tesla explained the nature and significance of the first creative attempts: "Our first endeavors are purely instinctive promptings of an imagination vivid and undisciplined. As we grow older, reason asserts itself and we become more and more systematic and designing. But those early impulses, though not immediately productive, are of the greatest moment and may shape our very destinies." (ibid., 17). In order for a new creation to emerge as a product of a creative act it must be preceded by a series of attempts mediated by the power of imagination, spontaneity, immediacy, fantasy, perception, lucidity. The freer the play of these forces, the higher the possibility of their creative expression. By stimulating these first creative attempts, the teacher can help not only in the development of giftedness, but also in raising the level of self-awareness of students.

The question is how can the education system contribute to the creative development of giftedness. Very often one can hear recommendations of school psychologists addressed to parents and teachers about the necessity of monitoring and detecting affection and affinity of children and their proper guidance and orientation. In doing so one ignores the fact that parents and teachers are really limited. Parents, by the lack of "school of parenting", which would make them capable of proper participation in the education process, and teachers by the existing system and educational programs. If we assume that parents could instinctively sense or have a clear insight into their child's preferences, or that teachers could identify them, the question that remains is the possibility of their participation in the realization of giftedness. (Porter L., 2005) The ways in which teaching is organized and the programmed concept of work often do not provide enough possibilities for undisturbed and free development of students' abilities. In circumstances where there is no differentiation of students due to the type and level of 
excellence of their abilities and when the curriculum is not adapted to them, nor their teachers, there is little space for creative work. (Guilford, 1968)

In this sense, students who, for example, have a developed sense of music or visual arts i.e. have auditory or visual potential, have no possibility of getting the kind of education that fits their gifts, and therefore their needs through the regular classes. They will, according to the generally applicable curriculum, have an hour per week of music or art, but all students, regardless of having mathematical intelligence or not, will have a required five hours of mathematics in the same curriculum.

What remains for parents and teachers in these circumstances is to involve children in extracurricular activities or supplemental instruction classes in subjects they are interested in in order to gain a broader knowledge. This establishes a parallel system of education: curricular, in large percentage inadequate to students' needs, which is therefore seen as imposed, and extracurricular, in which students find themselves through affirmation of their own abilities.

Do we need educational programs doubled? What needs to be done in order for regular education to become receptive to the needs of young people, in which they would like to participate and confirm, not deny themselves. If we look at education not only as an opportunity for acquiring knowledge and skills, but also as a way for becoming a better person, a new concept of education would have to include individualization of the curriculum that would suit abilities and preferences of each student. In this context, for teachers to properly exercise their role it is essential that, in addition to having relevant intellectual features and morality, they apply valid methods of work.

An important starting point for every teacher is applying the principle of "Know thyself". This record which has been preserved at Delphi, and which was the starting point of Socrates' educational work, contains a demand for self-knowledge as a basis for personal growth. It includes focus on oneself, listening to one's own needs, initiating internal strengths towards recognition of possibilities and limitations within one's own nature. Such introspection in order to focus the view on one's own state of mind, demands, especially with young people (students), a good expert (teacher), one who will cheer, encourage, properly direct, using reliable methodological principles.

Table 2 shows self-evaluation of teacher competencies to recognize gifted children (at the scale 1 to 10 ) in the stated research, according to which it can be seen that pre-school teachers find themselves least competent, class teachers mainly think they are competent (but they have also stated that they need additional education), while the examined teachers have estimated themselves as the most competent, due to the highest marks they had given to themselves.

Table 2. Self-evaluation of teacher competencies to recognize gifted children (Milovanovic, 2012)

\begin{tabular}{ll}
\hline & $\mathrm{M}$ \\
\hline PRESCHOOL TEACHERS & 4.67 \\
CLASS TEACHERS & 8,56 \\
TEACHERS & 9.32 \\
\hline
\end{tabular}

Being accustomed to introspection shall contribute to a better relationship with one's own gifts, not only for a clearer awareness of them, but for the immediate pleasure that comes from their realization through the schoolwork. (Tesla, 1995). Introspection is a strenuous spiritual exercise that develops the virtue of self-control. N. Tesla said on the importance of knowing oneself: "From childhood I was compelled to concentrate attention upon myself. This caused me much suffering but, to my present view, it was a blessing in disguise for it has taught me to appreciate the inestimable value of introspection in the preservation of life, as well as a means of achievement... Most persons are so absorbed in the contemplation of the outside world that they are wholly oblivious to what is passing on within themselves." (Tesla, 1995: 26).

One of the most important gifts that should adorn teachers, and that they should encourage in their students is wonderment. (Aristotle 2002, 14) Its presence in a naive form in children, illustrates how innate it is to human beings. It is a manifestation of the most original human cognitive impulses and the initiator towards the unknown. In wonderment everything is presented through a veil of secrecy that dares us to look into it. It possesses a call for openness to the world, observation, anticipation of the invisible in the visible, hidden in the apparent. 
Unfortunately, due to inadequate attention to this gift, it is now almost completely suppressed, even to the point beyond recognition, despite its extraordinary importance for the cognitive process signified in Aristotle's Metaphysics. If we ask ourselves what factors in the education system contribute to this state and what we can do to get out of it, we will find the answer in the teachers' relation to curiosity and interest of students which are very similar to wonderment in their nature. The existing character of education is such that it requires students to memorize certain material and simply reproduce it rather than focus on their methodological introduction to the process of free, reasoned and creative thinking. This systematically suffocates their natural and healthy desire for truth. And without this desire no knowledge, however great, has any real value. Not only because it is often not understood conceptually, but primarily because it is not born in the fight of one's own soul, it is not the product of opposing argument, it is not a product of one's own curiosity, i.e. thirst for knowledge. A good answer to the question of what needs to be done to stimulate the students' ability of free thought, we find in our well-known and internationally recognized scientist, geographer and anthropologist J. Cvijic: "Professor should through healthy freshness, value and power of his own voice, work and life trigger action and more intense life in others. In the course, students should see the professor's struggles and efforts in addressing the problem and seeking the truth. Often the solution to the problem is only partial, gaps and scarcity of observations appear, and only after new observations have been made he returns to it. Nothing has such a huge impact on students, as the birth of thought process, which they all feel ... It is quite different when the same problem is presented with a solution. It may be understood by anyone who possesses certain knowledge, but seldom can it cause that fertile spiritual fermentation as in students of the course." (Cvijic, 1923:33) Introduction to the thinking process involves joint work of teachers and students, coming up with new ideas and their interaction. Given solutions do not have this power of attraction because they are not mediated by the dynamics of thought energy, and have no effective power because they do not evoke the spirit, but leave it passive. It is therefore of great importance to properly methodically direct students' attention on their own intellectual movement that would encourage their thirst for knowledge.

Among the gifts that a teacher should possess and at the same time foster in students is the gift of observation. It consists of keen ability of sensory and spiritual perception which perceives and differentiates specific phenomena. This gift is important for teachers in the cognitive sense when it is used in the form of scientific method, and in educational sense if behind the visible surface of students' behavior their spiritual eye succeeds to discover the energy that exists and acts in a hidden way. On the need and the mode of development of the observing spirit M. Pupin says:" Is it not obvious that the very nature is a better teacher and a leader to those who learn from it through the research of its occurrences than all the knowledge that is acquired in our schools. And is that not because nature as a teacher first and foremost seeks to develop the spirit of observation". (Pupin, 2010: 171). This statement quite eloquently explains the necessity of live, immediate connection of the spirit and nature, the knowledge that arises in communication with nature, its language which is learned by listening and through which our senses sharpen and enrich the spirit. Depending on what it is directed at, observation can develop different abilities. Thus, self-observation sharpens awareness of oneself known as the virtue of humility that provides a clear insight into one's own being. By observing others one cultivates one's own emotional intelligence as a form of subtle sensibility that makes us capable of experiential understanding of the most delicate mental state. By observing the external world one develops the ability of spatial perception, seeing different relations, sizes and shapes, the power of visualization. On a higher spiritual level, this power is developed into the ability of abstraction, i.e. contemplative separation of important from unimportant, to the level of mental intuition where it represents the power of immediate perception of truth. (Fryer M., 1996).

One of the important traits that a teacher should possess, and encourage it in students is rhetorical ability. As an ontological possibility of understanding and expressing thoughts and feelings, the power of speech distinguishes humans from other living beings. However, as a particularly strong ability it is present only in some people. Remarkable tendency to eloquence, poetry and prophecy in ancient Hellas was considered a gift of Gods. Word of mouth elevated from ordinary experience to the level of logical discipline based on scientific principles and broad erudition always had a fruitful power of influence on the human soul. Prerequisites for a rhetorical skill are natural gift, common sense, a rich repository of knowledge associated with the theory and practice. (Clarke, 1968.) Thus, eloquence is not complete and sufficient unless it is educated.

By asking the question in Phaedrus, what is a good speech based on? - Plato answers - "it must be based on truth and persuade the audience of the validity of the argument." (2003:262 C). Understanding this stance in the context of teaching means that the teachers' rhetorical skills include knowledge of scientific truth and the ability of persuasion through rhetorical arguments. In order to achieve this it necessary not only to possess a good knowledge of the scientific method, but also a knowledge of the nature of the human soul in order to be able to 
act on it. If rhetorical ability means "influencing the soul through words" then beside analytical the teacher should also use a means of expression that will draw the attention of students, appropriately introduce them to true knowledge and gain their trust. The clear and distinct speech can only come from a logical harmoniously related thought (Baum, 2006). This requires power of conception, discipline of mind, focusing on the main thought and conciseness of presentation. In this sense, one should interpret Fichte that no one who does not know how to think and who does not know how to collect ideas and govern them can learn how to speak.

Will teachers get students' attention through their speech and cause them to start searching for the truth, will they achieve validity of the argument, and will they evoke pleasant feelings, depends on how they approach the subject of their argument. Whether they do it with spiritual fervor or mechanically, with a zest that includes experience of thought or with cold and indifferent attitude, with a deep faith in what is said or with uncertainty? Inward conviction permeated with true feelings and faith gives special power to spoken words making them more effective. "When a man wants to express a thought and to win his audience he must first of all dress that expression in faith, which shows that his thought is justified, and feelings which shows that he is delighted with his thought." (Djuric, 2002). A good speech should express a true thought, great sensitivity and noble character. Since it is not focused only on the mind, but also the "heart and sensibility of the audience" it is important to be expressed in a logical consistency, proper language and harmonious style. This means that in addition to logical and aesthetic it should also should include an ethical segment. This is what allows mild and moderate soothing that gives the speech an appropriate and harmonious tone. Teachers who succeed to uniquely connect a simple, solemn and modest style in their speech, and evoke logical conviction, creative excitement in students and gain their trust, satisfy the basic prerequisites of a good speech (Brummett, 2006)

In addition to students' gifts which teachers can develop through educational process, it is essential that the educational activity stimulates strengthening of feelings of safety, satisfaction and a positive attitude to life (Combs, 1965). It is therefore essential that in addition to the introduction of general knowledge they also transfer the knowledge of fundamental values that underpin a healthy and happy life, and that they be exemplary figures through their own views, attitudes and action. (Quintilian, 1985). Thus, in addition to the very careful detection of different abilities in students and motivation of their development through successful acquisition of teaching materials, the role of teachers is to deal with complex issues, create conditions for free, creative expression, and carefully nurture their purest spiritual aspirations and help in the formation of human character.

\section{Final Considerations}

In the educational process in which young people are prepared for life, i.e. to cope with various challenges and temptations, it is very important to help them discover their own gifts and develop them through continuous creative activity. Lack of awareness that the secret of success lies not only in the natural potentials, but also in the level of effort, and that the greatest achievements would not have been possible without their combination, denies the possibility of knowing that the phenomenon of work simultaneously affirms and confirms the best human characteristics and that it is the source of true happiness. The thesis of work that denies the human nature, that is a torture and a burden, is confirmed only in terms of wrong choices of one's profession. That is why teachers have a great responsibility to provide timely and adequate guidance to students towards their personal development and to affirm their healthy attitude towards creative work. For the effect to be greater the support of teachers is essential in order to develop students' self-belief, strong will, tenacity, competitive spirit, by adapting stimulating methods to their individual strengths. According to Aristotle's maxim that a man should be proud not of what he owes to fortune but of what he owes to himself (2001), the duty of teachers and students is to work on their own transformation in accordance with the gifts which they have been bestowed.

\section{References}

Aristotle. (2001). Rhetoric. Belgrade. Plato.

Aristotle. (2002). Nicomachean Ethics. BIGZ. Belgrade.

Aristotle. (2003). Metaphysics, Collection of debates. Zagreb. KruZak.

Baum, L. (2006). How to Permanently Cure Your Fear of Public Speaking. Tucson AZ.

Borkowski, J. G., \& Peck, V. A. (1986). Causes and consequences meta-memory in gifted children. In R. Strenberg, \& J. Davidson (Eds.), Conceptions of giftedness (pp. 182-200). Cambridge University Press.

Brummett, B. (2006). Rhetoric in Popular Culture. London-New Delphi.

Clarke, M. L. (1968). Die Rhetorik bei den Römern. S.113. Göttingen.

Combs, A. W. (1965). The professional education of teachers. Boston. 
Cropley, A. (1993). Creativity as an element of giftedness. International Journal of Educational Research, 1(1), 89.

Cvijic, J. (1987). Speeches and Articles (Collected Works, Vol. 3). Belgrade: SANU.

Dai, D., Swanson J., \& Cheng H. (2011). State of research on giftedness and gifted education: A survey of empirical studies published during 1998-2010. Gifted Child Quarterly, 55(2), 126-138. http://dx.doi.org/10.1177/0016986210397831

Djuric, M. (2002). History of Hellenic literature. Belgrade.

Feldhusen, J. (1986). A conception of giftedness. In Strenberg, R., \& Davidson, J. (Eds.), Conceptions of giftedness (p. 286). Cambridge: Cambridge University Press.

Fryer, M. (1996). Creative Teaching and learning. London. Paul Chapman.

Guilford, J. P. (1968). Intelligence, Creativity and their educational implications. San Diego.

Guilford, J. P., \& Hoepfner, R. (1971). Analysis and Intelligence, Mc Graw- hill, New York.

Jürgen M. (1988). Naturwissenschaft und Glaube. Scherz. Bern.

Milovanovic, R. (2012). The problem of the identification of the gifted: How (not) to recognise the gifted child? In Methods of working with talented students (Ed.). Marta Takacs, Subotica: Teacher Education in Hungarian.

Monks, F. J. Katzko, N. W., \& Boxtel, H. W. (1992). Education of the gifted in Europe (theoretical and research issues) 193-197. Amsterdam/ Lisse: Swets \& Zeitlinger.

Plato. (2002). Phaedrus. BIGZ. Belgrade.

Plato. (2003). The Republi. BIGZ. Belgrade.

Porter, L. (2005). Gifted Young Children: A Guide for Parents and Teachers. Allen \& Unwin. Crow's Nest.

Pupin, M. (2013). From Immigrant to Inventor. Belgrade. Institute for textbook publishing and teaching aids.

Quintilian, M. F. (1985). The Orator's Education (2nd ed.). Veselin Maslesa. Sarajevo.

Siegler, R. S., Kotovsky, K. (1986): Zwo levels of giftedness:shall ever the twin meet? In Strenberg, R., \& Davidson, J. (Eds.), Conception of giftedness (pp. 417-436). Cambridge: Cambridge University Press.

Sternberg, \& Lubart. (1993). Creative giftedness: A multivariate investment approach, Gifted Child Quarterly, $37(1), 7-15$.

Tesla, N. (1995). My Inventions. NT Club Belgrade: Nikola Tesla Museum.

Tesla, N. (1995). Selected Works, 1. Lectures. Belgrade: Institute for textbook publishing and teaching aids.

Tesla, N. (1995). Selected Works, 2. Articles. Belgrade. Institute for textbook publishing and teaching aids.

\section{Copyrights}

Copyright for this article is retained by the author(s), with first publication rights granted to the journal.

This is an open-access article distributed under the terms and conditions of the Creative Commons Attribution license (http://creativecommons.org/licenses/by/3.0/). 